ZOOLOGIA 32 (2): 162-170, April 2015

http://dx.doi.org/10.1590/S1984-46702015000200008

\title{
New morphological data on Solariella obscura (Trochoidea: Solariellidae) from New Jersey, USA
}

\author{
Ana Paula S. Dornellas ${ }^{1,2} \&$ Luiz R.L. Simone ${ }^{1}$ \\ ${ }^{1}$ Museu de Zoologia, Universidade de São Paulo. Caixa Postal 42494, 04218-970 São Paulo, SP, Brazil. \\ ${ }^{2}$ Corresponding author. E-mail: dornellas.anapaula@usp.br
}

\begin{abstract}
Anatomical data on Solariella obscura (Couthouy, 1838) are presented and analyzed. The main features of this species, when compared with other known trochoids, are: ctenidium with thick lamellae; enlarged ureter (that may indicate sexual dimorphism) instead of a modified urogenital papilla; odontophore very different from other trochoids such as Calliostoma, Agathistoma, Monodonta, and Gaza, with short m6, large mj and m4 pairs and absent m8 pair and posterior cartilages; esophageal valve surrounding the odontophore ventrally; anterior and mid-esophagus composed of several thin folds and a very wide cerebral ganglion. Solariella obscura differs from Solariella varicosa (Mighels \& Adams, 1842) by having lower spire, spiral cords weaker on the base and axial rib oblique. There are no differences between S. obscura and S. varicosa in the external morphology and radula. These internal anatomical data are described for the first time for a solariellid and might improve our understanding of the relationships within this taxon.
\end{abstract}

KEY WORDS. Anatomy; comparative data; North Atlantic; redescription.

Living Solariellidae is distributed in offshore waters worldwide and the fossil record is primarily in low latitudes during the Paleogene to higher latitudes in the Neogene (Hickman \& McLean 1990). It comprises Solariella Wood, 1842, Archiminolia Iredale, 1929, Bathymophila Dall, 1881, Hazuregyra Shikama, 1962, Ilanga Herbert, 1987, Microgaza Dall, 1881, Minolia Adams, 1860, Minolops Iredale, 1929, Spectamen Iredale, 1924, Zetela Finlay, 1927 (Hickman \& McLean 1990, Williams 2012).

Species belonging to Solariellidae are characterized by small, nacreous shells, short and straight radula, absent cephalic lappets, oral surface of snout with elongated papillae, anterior end of foot with well-developed lateral horns, and neck lobes bearing one or two tentacles (Herbert 1987, HickMAN \& McLean 1990, Williams et al. 2008). However, some shell characters in this family are convergent in both trochid subfamilies, Umboniinae and Margaritinae. Therefore, it has been inferred that shell characters in Solariellidae are misleading, and cannot be distinguished without knowledge of the external anatomy or radula (Hickman \& MClean 1990).

The generic name Solariella was used in the past in reference to a wide variety of trochids with a round aperture and broad umbilicus. The type species, Solariella maculata Wood, 1842 , is a fossil from the Pliocene, which makes it impossible to ascertain the state of its radular and soft parts. Nevertheless, recent species that resemble it and which are similar to the North Atlantic Solariella amabilis (Jeffreys, 1865) have been placed in Solariella by Herbert (1987), Hickman \& McLean (1990), and WARÉn (1993). Thus, Solariella sensu stricto has three pairs of epipodial tentacles, no prominent epipodial lobes and a radula with nascent lateromarginal plates (Herbert 1987, Marshall 1999).

Herein we describe and analyze the external morphology and certain anatomical structures of the North Atlantic Solariella obscura (Couthouy, 1838). In order to achieve new insights that might prove useful in future taxonomic studies.

\section{MATERIAL AND METHODS}

Specimens preserved in 70\% ethanol were extracted from their shells and subsequently dissected and photographed under the stereomicroscope. The terminology of the odontophore muscles follow Dornellas \& Simone (2013). All drawings were made with the aid of a camera lucida. Samples examined with the SEM (radulae and protoconchs) were mounted on stubs and coated with gold-palladium alloy. The specimens were analyzed and photographed under a stereomicroscope.

Anatomical abbreviations: af, afferent vein; ai, intestinal loop; an, anus; ac, anterior cartilage of odontophore; ax, axis; bc, subesophageal connective; cb, cerebrobuccal connective; cc, cerebral commissure; $c d$, cerebropedal connective; $c$, cerebral ganglion; cm: collumelar muscle; $\mathrm{cp}$, cerebropleural connective; ct, ctenidium; cv, ctenidial vein; df, dorsal fold; $\mathrm{dg}$, digestive gland; ef, esophageal fold; ep, epipodium; es, esophagus; et, epipodial tentacle; ev, esophageal valve; ft, foot; go, gonad; hg, hypobranchial gland; ho, horn; jw, jaws; la, left auricle; lg, labial ganglion; mb, mantle border; $\mathrm{mj}$, jugal muscles; $\mathrm{mt}$, mantle; nl, neck lobe; om, ommatophore; oa, opercular pad; os, osphadia; pc, pericardium; pe, pedal ganglion; pl, pleural ganglion; ps,

2015 | Sociedade Brasileira de Zoologia | www.sbzoologia.org.br | www.scielo.br/zool

All content of the journal, except where identified, is licensed under a Creative Commons attribution-type BY-NC. 
papillary sac; pt, postoptic tentacle; ra, radula; ru, right auricle; rk, right kidney; ro, rod; sc, spiral caecum; sg, salivary gland; sk, skeletal rod; sm, stomach; sn, snout; st, statocysts; te, cephalic tentacle; ur, ureter; ve, ventricle.

Institutional acronyms. (USNM/NMNH) National Museum of Natural History, Smithsonian Institution, Washington, DC.

Material analyzed. Types: United States, between Marblehead and Nahant, Massachusetts Bay, 7 specimens, MCZ 154825. United States, off New Jersey, North Atlantic Ocean, $39^{\circ} 02^{\prime} 54^{\prime \prime} \mathrm{N} 73^{\circ} 47^{\prime} 06^{\prime \prime} \mathrm{W}, 6$ specimens, USNM $828340^{\prime}$ $3919^{\prime} 18^{\prime \prime} \mathrm{N} 73^{\circ} 10^{\prime} 06^{\prime \prime W}, 2$ specimens, USNM 828343.

\section{TAXONOMY}

\section{Solariella obscura (Couthouy, 1838)}

Figs. 1-34

Turbo obscurus Couthouy, 1838: 100 (pl. 3, fig. 12).

Solariella obscura: Tryon, 1889: 308 (pl. 57, figs. 44, 45); Locard, 1903: 43; Cushman, 1906: 16; Odhner, 1912: 70; Johnson, 1915: 89; Smith, 1951: 79 (pl. 31, fig. 19; pl. 71, fig. 16); Lopes \& Cardoso, 1958: 62; MacGinite, 1959: 80; Talmadge, 1967: 236; Abbott, 1974: 40 (fig. 271); Procter, 1993: 172.

Margarites albula Gould, 1861: 36.

Margarita obscura: Gould, 1870: 283 (fig. 545).

Margarita bella Verkrüzen, 1875: 236.

Margarita obscura var cinereaeformis Leche, 1878: 45 (pl. 2, fig. 24).

Margarita obscura var intermedia Leche, 1878: 45 (pl. 2, fig. 25).

Solariella laevis Friele, 1886: 14.

Solariella obscura var bella (Verkrüzen): Tryon, 1889: 310 (pl. 64, figs. 57, 58); Blaney, 1906: 111; Johnson, 1915: 89; Lopes \& Cardoso, 1958: 62.

Machaeroplax obscura var planula Verrill, 1882: 532; Johnson, 1915: 89 (pl. 17, fig. 6); Lopes \& Cardoso, 1958: 63.

Machaeroplax obscura var carinata Verrill, 1882: 532; Johnson, 1915: 90; Lopes \& Cardoso, 1958: 62.

Solariella obscura var multilirata Odhner, 1912: 79; Lopes \& Cardoso, 1958: 62.

Type. Cotypes, 7 shells, MCZ 154825.

Type locality. Between Marblehead and Nahant, Massachusetts Bay, USA. In fish stomach.

Distribution. Arctic circumpolar; south of New England; eastern and western Greenland; Iceland; Canada, Labrador; USA, Maine, Massachusetts, Connecticut (WARÉn 1993, ROSENBERg 2009).

Description. Shell (Figs. 1-10, 22, 23): up to 51/2 whorls, 8 $\mathrm{mm}$ in height and $9 \mathrm{~mm}$ in diameter; deeply umbilicate; shape trochoid, whorls rounded or angular, suture impressed. Color grayish to pinkish tan, peristome thin and nearly complete, often worn, revealing iridescent color. Protoconch (Figs. 22, 23) of 1 whorl lighter-colored, smooth; about $250 \mu \mathrm{m}$ diameter. Spire sculptured by weakly beaded spiral cords; about 12 cords on last whorl. Some specimens with strong cord on middle whorl (Figs. 3,6 ), forming carinate shoulder. Base weakly convex, with about 20 cords, thinner than those on spire; smooth. Strong beaded cord surrounding umbilical area; umbilical area with 7-10 cords. Umbilicus wide and deep, about $20 \%$ maximum shell width, funnel-shaped. Aperture rounded, inner surface iridescent; 75\% of shell length, $\sim 55 \%$ of shell width.

Head-Foot (Figs. 24, 25, 34). Head bulging approximately in middle region of head-foot. Snout wide, cylindrical; distal end wider than base; distal surface papillated; papillae long, thin, cylindrical, with rounded tip. Outer lips mid-ventrally incomplete, mouth located in middle portion of ventral surface of snout. Pair of cephalic lappets absent. Cephalic tentacles (Fig. 24: te) 20-30\% longer than snout, sometimes asymmetrical in relation to one another, covered by small papillae, dorso-ventrally flattened, grooved, narrowing gradually up to lightly pointed tip. Ommatophore on outer base of cephalic tentacles, length $1 / 5$ of tentacle length. Eyes dark, rounded, occupying anterior edge of ommatophore.

Foot thick, occupying half of total head-foot length; whitish, non papillated; anterior end truncated and drawn out laterally into two long processes (horns). Epipodium (Fig. 25: ep) surrounding latero-dorsal region of mesopodium, equidistant from sole and base of ommatophores. Right neck lobe with two tentacles, anterior tentacle postoptic (Fig. 25: pt); left neck lobe with one tentacle. Three pairs of epipodial tentacles (Figs. 24, 25) symmetrical on both sides; epipodial sense organs at base of epipodial tentacles. Opercular pad (Figs. 25, 34: oa) rounded, located in median dorsal region, with free edge in posterior area; posterior end with several chevron furrows, apex pointed posteriorly and two pairs of longitudinal furrows on median line. Furrow of pedal glands along entire anterior edge.

Operculum (Figs. 11, 12). Up to $\sim 2.5 \mathrm{~mm}$ in diameter and $\sim 7$ whorls, closing entire aperture, corneous, thin, with central nucleus. Inner side convex, outer side concave. Color yellowish gold.

Mantle organs (Figs. 13, 26-28). Pallial cavity of 3/4 whorl. Mantle border (Fig. 26: mb) thick, white; anterior end papillated, occupying $1 / 3$ of mantle border. Gill located on left side of pallial cavity; less than half of width and height of pallial cavity; projecting anteriorly, sustained by gill rod, lacking suspensory membrane (Fig. 26: sk). Anterior end of gill narrow, with acuminate tip. Ventral lamella larger than dorsal lamella (Figs. 27). Afferent gill vessel $\sim 3 / 4$ of gill's length, originating in transverse pallial vessel, running along distal region of central axis of gill. Transverse pallial vessel $\sim 1 / 5$ of afferent vessel length, originating in left nephrostome and discharging in afferent gill vessel. Ctenidial vein (efferent gill vessel) length more than twice afferent vessel length, running along basal region of central axis of gill; posterior end of vein (half) free from gill filaments, lying parallel to afferent vessel up to pericardium. Osphradium rounded, whitish, located at base of gill rod. Hypobranchial glands (Figs. 26: hg) on both sides of rectum; more developed on left side. Rectum occupying $1 / 4$ of pallial cavity 

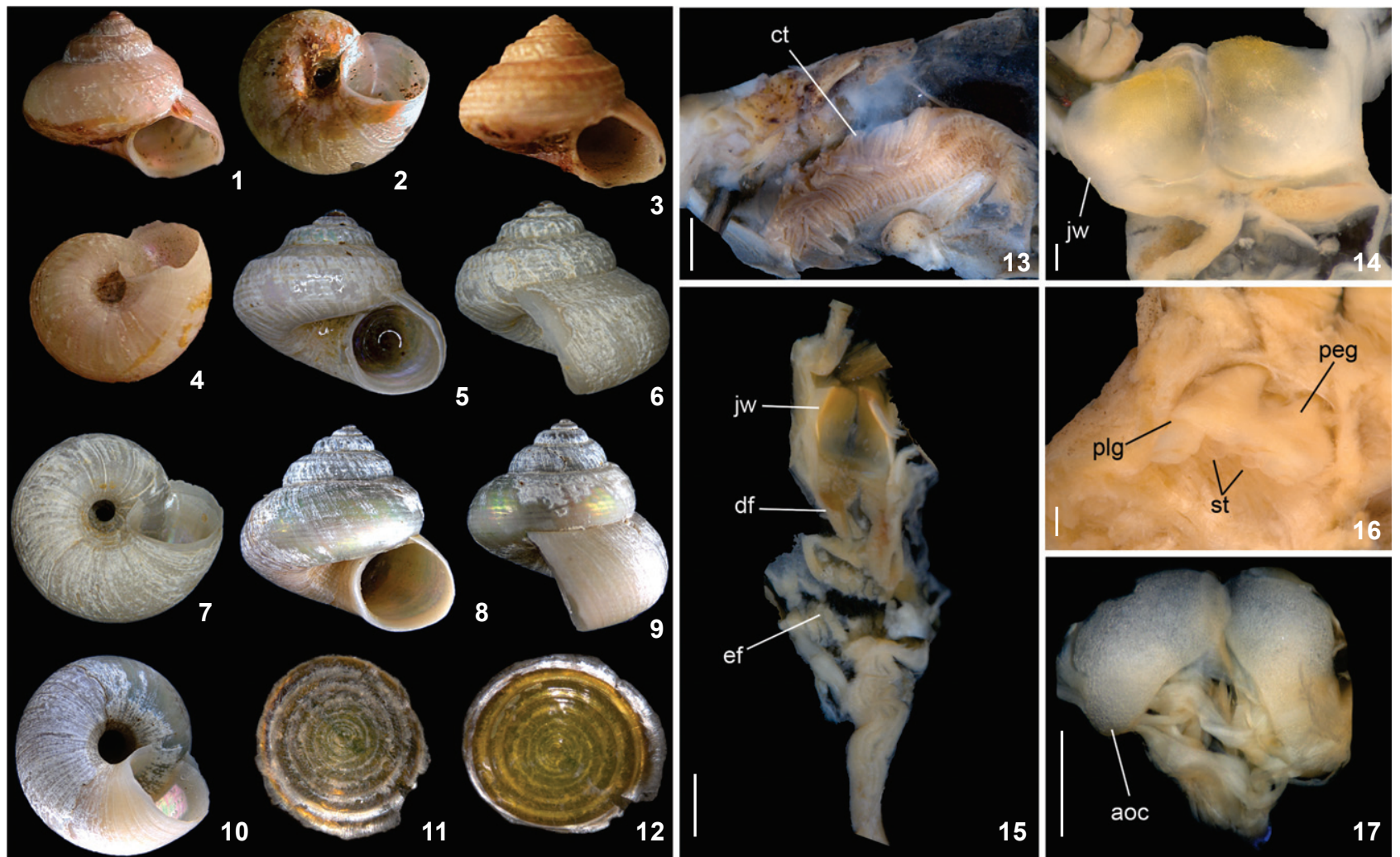

Figures 1-17. Solariella obscura. (1-12) Shell and operculum: (1-4) Cotypes MCZ 154825, apertural and umbical views: (1-2) 7.2 mm height $\times 8.5 \mathrm{~mm}$ width, (3-4) $7.2 \mathrm{~mm} \times 8.6 \mathrm{~mm}$. (5-12) USNM 828340, shell and operculum; (5-10) shell, apertural, lateral and umbilical views: (5-7) $5.8 \mathrm{~mm} \times 5.5 \mathrm{~mm},(8-10) 8.9 \mathrm{~mm} \times 9.1 \mathrm{~mm}$; (11-12) operculum, external and internal views, $3 \mathrm{~mm}$ diameter. (13-17) Anatomy: (13) pallial cavity, ventral view; (14) jaws, ventral view; (15) foregut, anterior and mid-esophagus opened longitudinally, ventral inner view, odontophore removed; (16) pedal and pleural ganglia in situ, dorsal view; (17) anterior odontophore cartilages, muscles removed, ventral view. Scale bars: $14,16=0.2 \mathrm{~mm} ; 13,15,17=0.5 \mathrm{~mm}$.

width, sigmoid; posterior region under kidneys. Anus siphoned, preceded by pleated and short free end, located on posterior right side of pallial cavity. Kidneys length more than half of rectum length, located on posterior region of pallial cavity.

Visceral mass (Fig. 34). Pericardium and posterior portion of right kidney exposed on pallial cavity roof. Stomach and spiral caecum (sc) located $1 / 3$ whorl posterior to pallial cavity. Digestive gland (dg) located on left side and gonad (go) on right side, both posterior to right kidney.

Circulatory and excretory systems (Figs. 26, 28). Pericardium located between pallial cavity and visceral mass (Fig. 26: pc), close to median line and immediately posterior to kidneys. Left side of pericardium receiving ctenidial vein and right side receiving right pallial vein. Ventricle volume $1 / 3$ of pericardium volume; surrounding rectum and flanked anteriorly by left auricle and posteriorly by right auricle; left auricle ventral, triangular, occupying about half of pericardium volume; right auricle weak, smaller than left one (Fig. 28). Papillary sac (or left kidney) base oval, wide, gradually narrowing towards anterior portion, ending at left nephrostome; inner wall covered by numerous thin, long papillae. Right kidney (Fig. 28: ur, rk) divided into two regions; anterior region as hollow tube (ureter), right nephrostome located in anterior region; ureter might be as large as papillary sac (probably males) (Fig. 26) or twice papillary sac width (probably females) (Fig. 28); no mucus observed in females ureter. Posterior region spreading around visceral mass immediately beneath mantle, encircling inner surface of columellar muscle. Kidney expanding ventrally, covering half of right surface of adjacent visceral hump.

Digestive system (Figs. 14, 15, 17, 18-21, 29-33). Oral tube length $\sim 1 / 2$ odontophore length; walls with circular muscles (Figs. 29, 30); basal region with thick oblique fibers (Fig. 31: $\mathrm{mj}$ ), originating gradually from dorsal surface, close to median line; fibers running posteriorly towards both sides, inserting in ventral surface of odontophore. Jaw plates (Fig. 14) thin, light brown, rounded, occupying half of odontophore length. Pair of dorsal folds starting posteriorly to jaws (Fig. 15: df), with each fold bending and forming two partially overlapping 

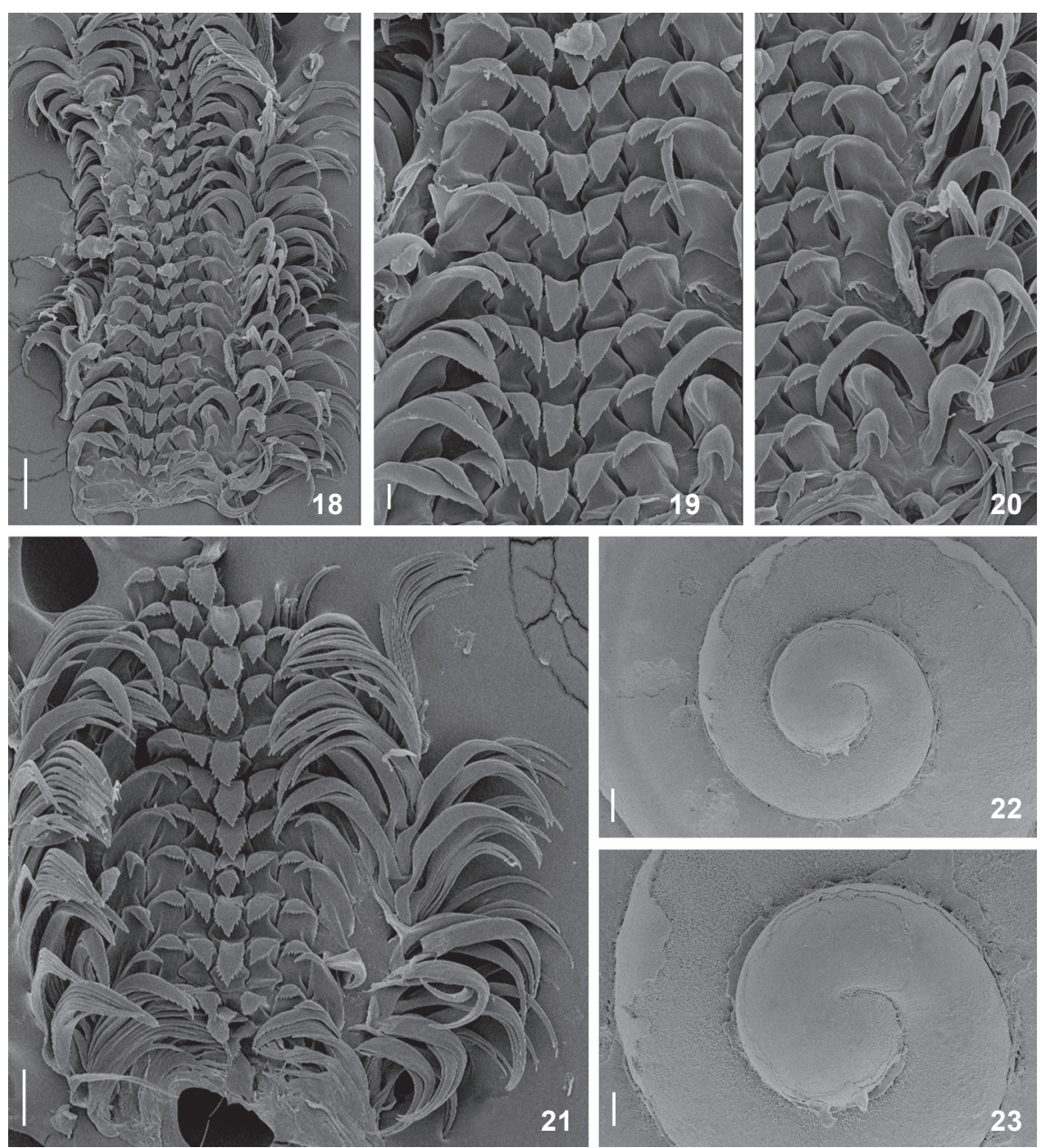

Figures 18-23. Solariella obscura, structures under SEM. (18-21) Radular ribbon: (18) middle region, whole view; (19) detail of central area, rachidian and lateral teeth; (20) detail of lateral and marginal teeth; (21) middle region, whole view; (22-23) Protoconch, apical views. Scale bars: $18=100 \mu \mathrm{m}, 19=20 \mu \mathrm{m}, 20=40 \mu \mathrm{m}, 21-23=60 \mu \mathrm{m}$.

slits. Series of transverse muscles separating outer surface of esophagus from odontophore. Odontophore about 1/3 longer than snout. Odontophore muscles (Figs. 29-33): m1 (Fig. 29): series of small jugal muscles connecting buccal mass with adjacent inner surface of snout and haemocoel; $\mathrm{m} 4$ broad and long pair of dorsal tensor muscles of radula and subradular membrane, originating on ventral and lateral surface of anterior cartilages, at some distance from median line, inserting along dorsal region of subradular membrane (exposed inside buccal cavity), with portion in radular ribbon preceding buccal cavity; m5: pair of large accessory dorsal tensor muscles of radula, originating on posterior surface of anterior cartilages, running firstly towards dorsal and median regions and subsequently anteriorly, with insertion in radular ribbon region; m6: horizontal muscle, uniting over half of ventral edges of both anterior cartilages; $\mathrm{m} 7$ : very small, thin pair of muscles, origi- nating in middle region of inner ventral surface of radular sac, running anteriorly (insertion not observed); m10: broad pair of ventral protractor muscles of odontophore, originating in ventral region of mouth and buccal sphincter, running posteriorly, inserting in posterior region of anterior cartilage; $\mathrm{m} 11$ : pair of thin ventral tensor muscles of radula, originating in middle region of ventral surface of anterior cartilage, running anteriorly and covering $\mathrm{m} 6$ and ventral surface of anterior cartilage, inserting on distal edge of subradular membrane; m11a; very long and thin pair of oblique ventral tensor muscles of radula, originating on anterior haemocoelic surface near pleural ganglia, running dorsally between anterior edge of anterior cartilages, inserting on distal edge of subradular membrane. Non-muscular structures of odontophore: ac: pair of anterior cartilages (Figs. 17, 33), antero-posteriorly elongated, flat, with anterior and posterior ends rounded, same length as 

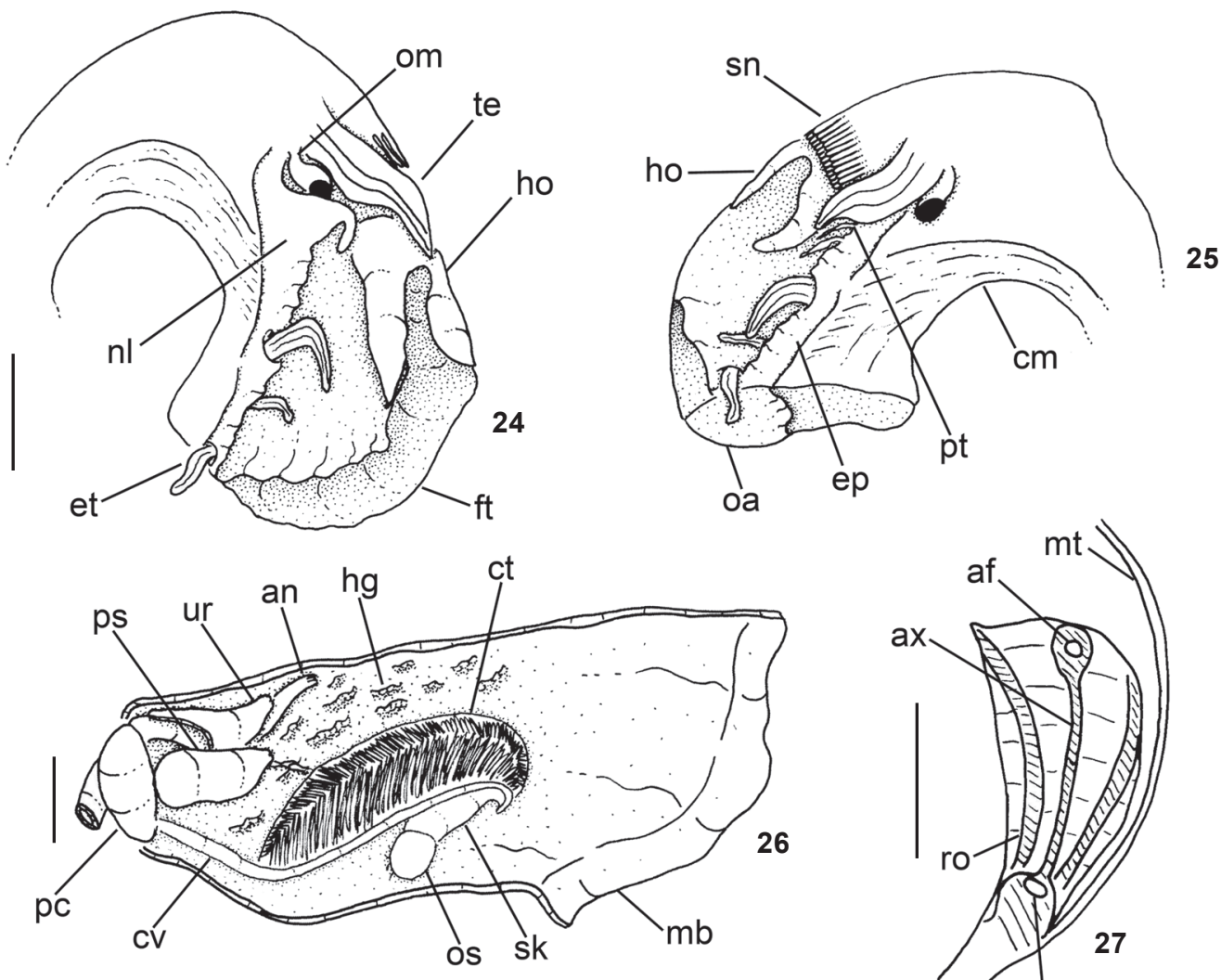

26
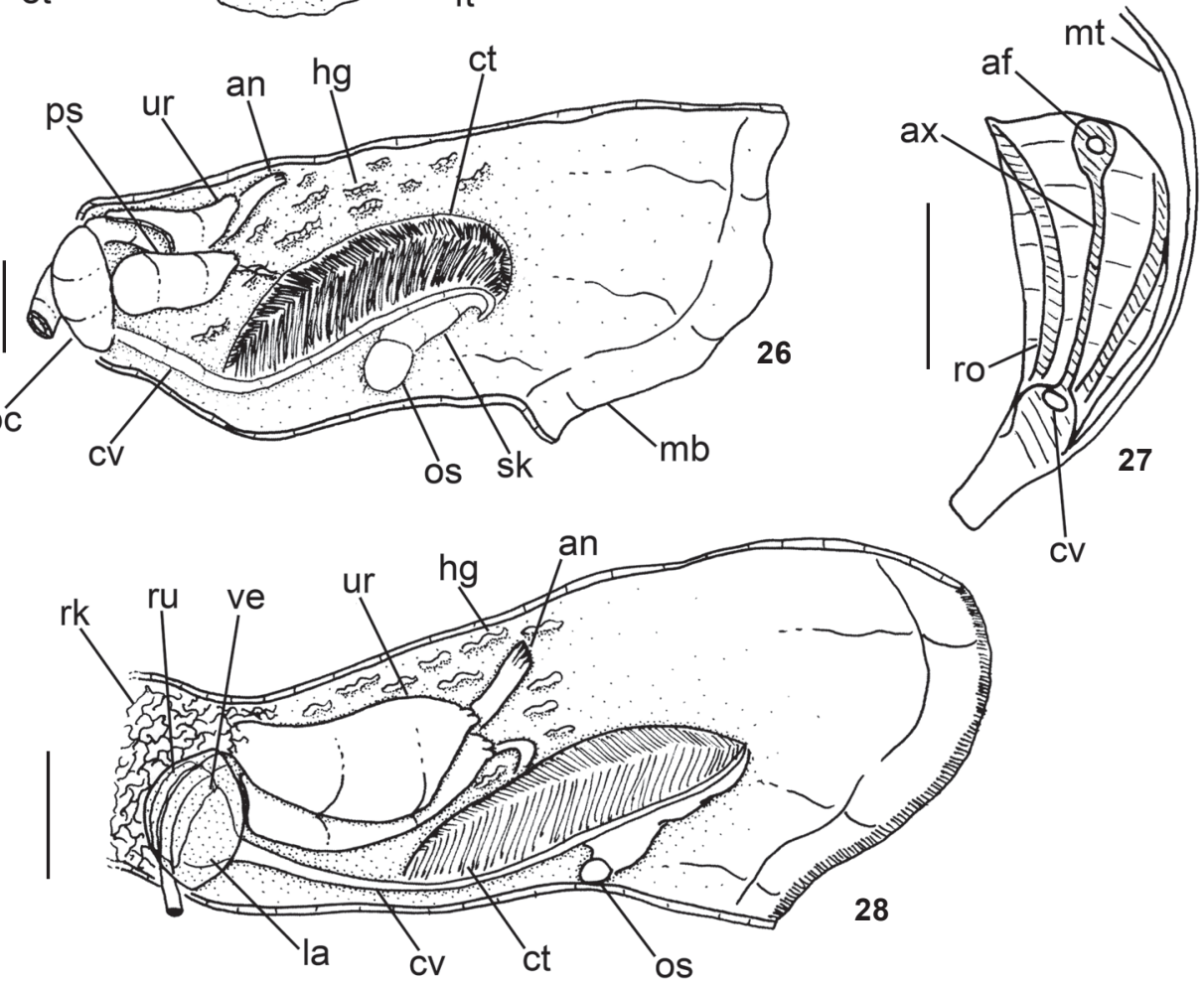

Figures 24-28. Anatomy of Solariella obscura: (24-25) head-foot, right and left views; (26) pallial cavity roof, male, ventral view; (27) transverse section in middle region of ctenidium; (28) pallial cavity roof, female, ventral view. Scale bars: $24-26,28=1 \mathrm{~mm} ; 27=0.5 \mathrm{~mm}$.

odontophore. Pair of posterior odontophore cartilages absent. Odontophore cartilages whitish, rough; br: subradular membrane covering most of the exposed surface of odontophore in buccal cavity, where most of intrinsic odontophore muscles insert; sc: subradular cartilage maintaining radular ribbon.

Radular sac short (Fig. 31: ra), as long as odontophore. Radular nucleus (Fig. 32) located on ventral side of odontophore. Central complex (rachidian and laterals) well-developed, with interlocking process and correspondent sockets (Fig. 18); shafts expanding laterally, hood-shaped. Rachidian large (Fig.
19), triangular, cutting edge with projection turned posteriorly (almost $90^{\circ}$ ) and covering posterior end of preceding tooth; tip narrowly tapered, serrated; base and cusp with within-column interaction. Four lateral teeth (Figs. 20, 21); cusps oriented toward midline of radula, most strongly serrate along their outer margins; three inner lateral teeth similar to rachidian in shape; outermost lateral teeth broad, large, length twice of inner teeth length. Lateromarginal plate not observed. Marginal teeth (Fig. 18) as long as outermost lateral teeth, slender, serrate, $\sim 10-12$ teeth pairs. Anterior esophagus with esophageal 

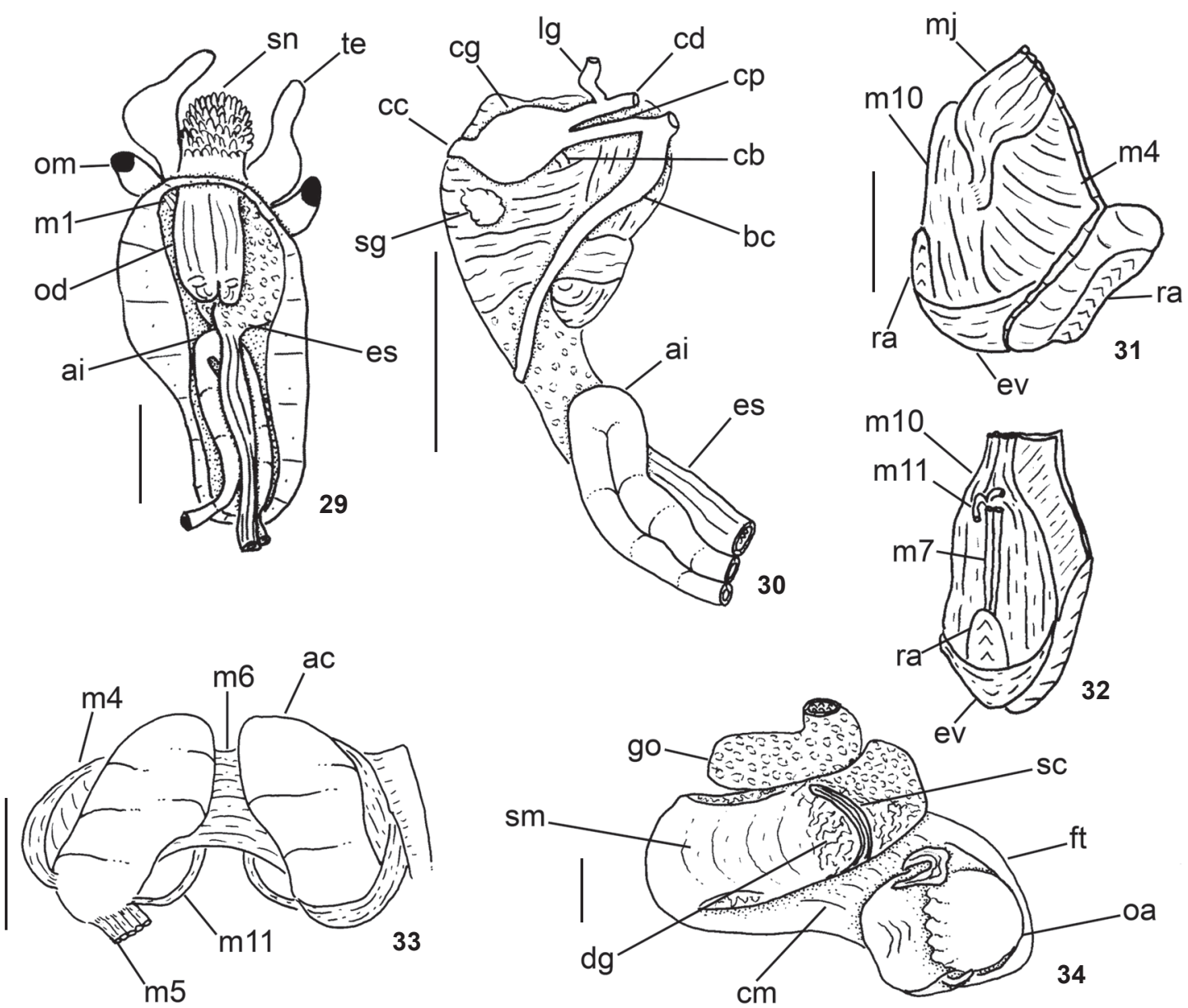

Figures 29-34. Anatomy of Solariella obscura: (29) head-foot haemocoel, ventral view, foot and columellar muscle removed; (30) buccal mass and central nervous system, right view; (31-32) odontophore, left, and ventral views; (33) odontophore, dorsal view, radular ribbon removed, left $\mathrm{m} 5$ extracted and reflected, m10 extracted; (34) head-foot and visceral mass, whole apertural view. Scale bars: 29 $30,34=1 \mathrm{~mm} ; 31-33=0.5 \mathrm{~mm}$.

valve covering ventral surface of odontophore. Anterior and mid esophagus (Fig. 15) with folds forming shallow chambers; epithelium entirely covered by villous papillae. Posterior esophagus narrow, with some thin longitudinal folds on inner surface. Stomach not observed. Spiral caecum with $1 / 2$ counter clockwise (in dorsal view) whorls. Intestine (Figs. 26, 28-30) very wide, running anteriorly forward inside to cephalic haemocoel, bending abruptly, forming wide loop (Fig. 30: ai); anterior region of visceral mass with small loop surrounding kidney and pericardium, exiting in right-posterior corner of pallial cavity. Rectum and anus described above (pallial organs).

Central nervous system (Figs. 16, 30). Nerve ring surrounding anterior half of buccal mass. Cerebral ganglia rounded, located in lateral region of buccal mass (Fig. 30: cg), size $\sim 1 / 3$ of odontophore size; commissure thick, long, dorso-ventrally flattened; cerebropleural and cerebropedal (Fig. 30: cp, cd) connectives long, thin, originating in anterior region of cerebral ganglia and running ventrally and back to pedal and pleural ganglia. Labial ganglia (Figs. 30: lg) 1/6 of cerebral ganglia, located in ventro-lateral region of buccal mass, anteriorly to cerebral ganglia; connected to cerebral ganglia by short cerebrolabial connective. Buccal ganglia posterior to cerebral ganglia; connected to cerebral ganglia by a buccolabial connective. Pleural and pedal ganglia (Fig. 16: pl, pe) close to each other, located inside pedal musculature immediately below ventral surface of haemocoel; both of about half size of cerebral ganglion. Pedal commissure thick, very short. Pedal nerve running forward from each pedal ganglion, surrounding medial pedal blood sinus. Supra-esophageal connective emerging from right pleural ganglia. Subesophageal connective (Fig. 30) emerging from left pleural ganglia. Statocysts (Fig. 16: st) rounded, bright, located very close to posterior side of pedal ganglia. 


\section{DISCUSSION}

The organs and systems of $S$. obscura are congruent with the features of solariellid mentioned by previous authors (HERBERT 1987, HickMAN \& MCLEAN 1990, WilLiaMs 2012), such as: small and nacreous shells; presence of a ring of digitate papillae around the snout; short radula with 20-30 transverse teeth rows; anterior end of foot bilobed, forming the horn; long and thick cephalic tentacles, and an eye-stalk much shorter than the cephalic tentacle. Some of these features are not exclusive to solariellids, however, especially when compared with other trochoids. The presence of digitate papillae around the snout can also be found in Gaza Watson, 1879 (Simone \& Cunha 2006), and the Umboniinae also have a bilobed foot (HickMAN \& MCLEAn 1990, pers. obs.). The radula, on the other hand, is the main structure for characterizing this family and its genera (HERBERT 1987, Marshall 1999), being short (20-30 rows of teeth), with reduced number of marginal teeth ( 10 per half row).

The Artic species Solariella varicosa (Mighels \& Adams, 1842 ) is similar in shape to $S$. obscura, but differs by having a taller spire, strong oblique axial rounded ribs and stronger spiral cords on the base. The distributions of both species overlaps in the Artic, south of Labrador and northern Canada (WARÉn 1993). The neck lobe shows a variety of shapes among trochoids and might be used to diagnose subfamilies, genera and even species (Hickman \& McLean 1990, Dornellas \& Simone 2013). They are usually digitate, fringed or smooth, as well as symmetrical or asymmetrical to each other according to the taxa. The neck lobes of solariellids show some inter-generic variation in shape (Herbert 1987, Marshall 1999) and are characterized by the presence of one or two short tentacles, the right neck lobe bearing the postoptic tentacle located at its anterior edge (Fig. 25: pt). The neck lobe of $S$. obscura was reported as being virtually identical to that of $S$. varicosa (WARÉN 1993: 161, figs. 4a, b).

Regarding the pallial cavity, the ctenidium of S. obscura has a thick lamella (Fig. 13), as is the case in Solariella carvalhoi Lopes \& Cardoso, 1958 (pers. obs.), when compared with other trochoids such as Calliostoma Swainson, 1840, Monodonta Lamarck, 1789, Lithopoma Gray, 1850, Agathistoma Olsson \& Harbison, 1953, Gaza (Fretter \& Graham 1962, Righi 1965, Monteiro \& Coelho 2002, Simone \& Cunha 2006, Dornellas \& SIMONE 2013). The enlarged ureter in some specimens may indicate sexual dimorphism in Solariella (Fig. 28), differently from other vetigastropods in which the females have modified urogenital papillae (Woodward 1901, Fretter \& Graham 1962, Monteiro \& Coelho 2002, Dornellas 2012, Dornellas \& Simone 2013). However, this structure differs in shape among vetigastropods (see Dornellas \& Simone 2013).

The odontophore of $S$. obscura is different from that of other trochoids such as Calliostoma, Agathistoma, Monodonta and Gaza (Fretter \& Graham 1962, Righi 1965, Simone \& Cunha 2006, Dornellas 2012, Dornellas \& Simone 2013): the m6 is shorter (occupying only half of the cartilages' length); the mj and $\mathrm{m} 4$ pairs are larger (more than twice) than the current size; the $\mathrm{m} 8$ pair and the posterior cartilages are lacking. The buccal cavity differs from that of other trochoids by the esophageal valve surrounding the odontophore ventrally (Figs. 31, 32: ev), also observed in $S$. carvalhoi (personal observation). The salivary gland, located in latero-dorsal area of the buccal mass, is rounded and concentrated, similar to that observed in Tegula viridula (Gmelin, 1791), Monodonta labio (Linnaeus, 1758) and Lithopoma olfersii (Philippi, 1846) (Righi 1965, pers. obs.).

Usually, the anterior and mid-esophagus of vetigastropods is composed of four folds that compartmentalize it (FRETTER \& Graham 1962, Fretter 1964, Haszprunar 1988, Sasaki 1998, Dornellas \& Simone 2013). In S. obscura, on the other hand, the anterior and mid-esophagus are composed of several thin folds (Fig. 15). The presence of papillate glands covering the inner wall of that region, which is also present in S. obscura, is a morphological synapomorphy of the clade Vetigastropoda (Haszprunar 1988, Salvini-Plawen 1988, Sasaki 1998).

The radula of $S$. obscura is a typical solariellid radula, comprising a straight and short radular ribbon (as long as the odontophore), triangular rachidian, with the outermost lateral tooth being larger than the innermost teeth, and reduced number of marginal teeth ( 10 teeth along the same row). In Solariella, the radula is characterized by the presence of welldeveloped, elongate, cuspless lateromarginal plates (Herbert 1987). Solariella obscura and $S$. varicosa lack lateromarginal plates (Warén 1993, Fretter \& Graham 1977), whereas all southern Solariella bear lateromarginal plates (MARSHALL 1999).

Despite the gastric spiral caecum being a variable structure, a large spiral caecum is considered derived within Vetigastropoda. This structure opens ventrally in the posterior end of the stomach, more or less as continuous extensions of the typhlosoles (STRONG 2003). The 0.5 whorl long caecum observed in S. obscura (Fig. 31: sc) can also be found in Calliostoma depictum Dall, 1927, but the number of spiral caecum whorls seems to be an inter-specific feature rather than a generic one, because it may vary among congeners such as in Calliostoma and Lithopoma (Monteiro \& Coelho 2002, Dornellas \& Simone 2013).

The central nervous system of $S$. obscura demonstrates a trochoid pattern (SASAKI 1998) but the cerebral ganglion is proportionally wider (Fig. 30) when compared to those described in other vetigastropods (Fretter \& Graham 1962, SASAKi 1998, Simone \& Cunha 2006, Simone 2008, Dornellas 2012, Dornellas \& Simone 2013).

Solariellidae has been recently recognized as a family (Bouchet et al. 2005), with molecular studies supporting this rank (Williams et al. 2008, Williams 2012). As discussed above, several features seem to be exclusive of Solariellidae such as the above-mentioned radular pattern and external morphology. These features have also been further used to trace patterns between solariellid genera (Herbert 1987). On the other hand, there 
is no described data about the internal anatomy for any solariellid, and the new data described herein for $S$. obscura might improve our understanding about the relationships within this taxon, at generic and even suprageneric levels.

\section{ACKNOWLEDGEMENTS}

We thank Jerry Harasewych (NMNH) for lending us specimens; FAPESP (Fundação de Amparo à Pesquisa do Estado de São Paulo) process numbers 2010/18864-3; 2012/25173-2 for supporting our research; Lara Guimarães (MZSP) for help with the SEM; Diogo Couto for taking photos of the type, and Daniel Cavallari for helping with grammar revision.

\section{LITERATURE CITED}

Аввотт RT (1974) American Seashells. New York, Van Nostrand Rheinhold, 2nd ed., 663p.

Blaney D (1906) Shell-bearing Mollusca of Frenchman's Bay, Maine. The Nautilus 19(10): 110-111.

Bouchet P, Rocroi J, Frýda J, Hausdorf B, Ponder W, Valdés A, WARÉN A (2005) Classification and nomenclator of gastropod families. Malacologia 47(1-2): 1-397.

Couthouy JP (1838) Descriptions of new species of Mollusca and shells, and remarks on several polypi found in Massachusetts Bay. Boston Journal of Natural History 2: 53-111.

Cushman JA (1906) The Pleistocene deposits of Sankoty Head, Nantucket, and their fossils. Publications of the Nantucket Maria Mitchell Association 1(1): 1-21.

Dornellas APS (2012) Description of a new species of Calliostoma (Gastropoda, Calliostomatidae) from southeastern Brazil. ZooKeys 224: 89-106. doi: 10.3897/zookeys.224.3684

DoRnelLAS APS, SimONe LRL (2013) Comparative morphology and redescription of three species of Calliostoma (Gastropoda, Trochoidea) from Brazilian coast. Malacologia 56(1-2): $267-$ 293.

Friele H (1886) Mollusca II. The Norwegian North-Atlantic Expedition, 1876-1878 3: 1-35.

FRETTER V (1964) Observations on the anatomy of Mikadotrochus amabilis Bayer. Bulletin of Marine Science of the Gulf and Caribbean 14(1): 172-184.

Fretter V, Graham A (1962) British prosobranch molluscs. Their functional anatomy and ecology. Ray Society Publications, London, XVI+755p.

Fretter V, Graham A (1977) The prosobranch molluscs of Britain and Denmark. Part 2. Trochacea. Journal of Molluscan Studies 3(Suppl.): 39-100.

Gould AA (1861) Descriptions of shells collected by the North Pacific Exploring Expedition. Proceedings of the Boston Society of Natural History 8: 14-40.

Gould AA (1870) Report on the Invertebrata of Massachusetts. Boston, 2nd ed., 524p.
Haszrrunar, G (1988) On the origin and evolution of major gastropod groups, with special reference to the Streptoneura. Journal of Molluscan Studies 54: 367-441.

Herbert DG (1987) Revision of the Solariellinae (Mollusca: Prosobranchia: Trochidae) in southern Africa. Annals of the Natal Museum 28(2): 283-382.

Hickman CS, McLean JH (1990) Systematic revision and suprageneric classification of trochacean gastropods. Science Series, Natural History Museum of Los Angeles Country 35: 1-169.

Johnson CW (1915) Fauna of New England 13. List of Mollusca. Occasional Papers of the Boston Society of Natural History 7: 1-231.

LeCHE W (1878) Öfversigt öfver de af Svenska Expeditionerna till Novaja Semlja och Jenissej 1875 och 1876 Insamlade: HafsMollusker. Kongliga Svenska Vetenskaps-Akademiens Handlingar 16(2): 1-86.

LoCARd A (1903) Conquilles des Mers D'Europe. Turbinidae. Lyon, Société d'Agriculture, Sciences et Industrie de Lyon, p. 1-66.

Lopes HS, Cardoso PS (1958) Sobre um novo gastrópodo brasileiro do gênero Solariella Wood, 1842 (Trochidae). Revista Brasileira de Biologia 18(1): 59-64.

MacGinite B (1959) Marine Mollusca of Point Barrow, Alaska. Proceedings of the United States National Museum 10(3412): 59-208.

Marshall BA (1999) A Revision of the Recent Solariellinae (Gastropoda: Trochoidea) of the New Zealand Region. The Nautilus 113(1): 4-42.

Monteiro JC, Coelho ACS (2002) Comparative morphology of Astraea latispina (Philippi, 1844) and Astraea olfersii (Philippi, 1846) (Mollusca, Gastropoda, Turbinidae). Brazilian Journal of Biology 62(1): 135-150. doi: 10.1590/S151969842002000100016

OdHNER NH (1912) Northern and Artic invertebrates in the collection of the Swedish state Museum. Kungliga Svenska Vetenskapsakademiens Handlingar 48(1): 1-93.

Procter W (1993) Biological survey of the Mount Desert Region, part V - Marine Fauna. Philadelphia, Wistar Institute of Anatomy and Biology, 402p.

Righi G (1965) Sobre Tegula viridula (Gmelin, 1971). Boletim da Faculdade de Filosofia, Ciências e Letras da Universidade de São Paulo (Zoologia) 25: 325-390.

Rosemberg G (2009) Malacolog 4.1.1: A Database of Western Atlantic Marine Mollusca. Avalaible online at: http:// www.malacolog.org [Accessed: 22 December 2014]

SALVini-Plawen L von (1988) The structure and function of molluscan digestive systems, p. 301-379. In: Trueman ER, Clarke MR (Eds) The Mollusca: Form and Function. San Diego, Academic Press, vol. 11, 504p.

SASAKI T (1998). Comparative anatomy and phylogeny of the recent Archaeogastropoda (Mollusca: Gastropoda). The University of Tokyo Bulletin 38: 1-224. 
Simone LRL (2008) A new species of Fissurella from São Pedro e São Paulo Archipelago, Brazil (Vetigastropoda, Fissurellidae). The Veliger 50(4): 292-304.

Simone LRL, Cunha CM (2006) Revision of genera Gaza and Callogaza (Vetigastropoda, Trochidae), with description of a new Brazilian species. Zootaxa 1318: 1-40.

Sмiтн M (1951) East coast marine shells. Ann Arbor, Edwards Brothers, 4th ed., 314p.

STRONG EE (2003) Refining molluscan characters: morphology, character coding and a phylogeny of the Caenogastropoda. Zoological Journal of the Linnean Society 137: 447-554.

Talmadge RR (1967) Notes on the Mollusca of Prince William sound, Alaska. Part II. The Veliger 9(2): 235-238.

TRYON GW (1889) Manual of Conchology, with illustrations of the species. Trochidae, Stomatiidae, Pleutotomariidae, Haliotidae. Philadelphia, Published by the Author, vol. 1, $\# 11,519$ p.

VERKRÜZEN TA (1875) Bericht über einen Schabe - Ausflug in Sommer
1874. Jahrbücher der Deutschen Malakozoologischen Gesellschaft 2: 229-240.

VerRILl AE (1822) Catalogue of marine Mollusca added to the fauna of the New England region, during the past ten years. Transactions of the Connecticut Academy of Arts and Sciences 5: 451-587.

Warén A (1993) New and little known Mollusca from Iceland and Scandinava. Part 2. Sarsia 78: 159-201.

WiLLIAMs ST (2012) Advances in molecular systematics of the vetigastropod superfamily Trochoidea. Zoologica Scripta 41(6): 571-595. doi: 10.1111/j.1463-6409.2012.00552.x

Williams ST, Karube S, Ozawa T (2008) Molecular systematics of Vetigastropoda: Trochidae, Turbinidae and Trochoidea redefined. Zoologica Scripta 37(5): 483-506. doi: 10.1111/ j.1463-6409.2008.00341.x

WOODWARD MF (1901) The anatomy of Pleurotomaria beyrichii, Hilg. Bulletin of the Museum of Comparative Zoology 8: 215-268

Submitted: 8 October 2014

Received in revised form: 23 December 2014

Accepted: 5 February 2015

Editorial responsibility: Paulo da Cunha Lana 